\title{
Financing sustainable market actors in circular economy
}

\section{Mähönen, Jukka Tapio}

Edward Elgar

2019

Mähönen , J T 2019 , Financing sustainable market actors in circular economy . in E EftestøI-Wilhelmsson, S Sankari \& A Bask (eds), Sustainable and Efficient Transport :

Incentives for Promoting a Green Transport Market . Edward Elgar , pp. 95-116 . https://doi.org/10.4337/978178811

http://hdl.handle.net/10138/312349

https://doi.org/10.4337/9781788119283.00016

cc_by

acceptedVersion

Downloaded from Helda, University of Helsinki institutional repository.

This is an electronic reprint of the original article.

This reprint may differ from the original in pagination and typographic detail.

Please cite the original version. 


\title{
Financing sustainable market actors in circular economy
}

\author{
Jukka Mähönen
}

Abstract

\section{Setting the scene}

Modern societies are highly centralized.* They are organized politically as municipalities, regions, states, often even as federations often constitutionally in hierarchical orders, and economically as markets with centrally controlled multinational business groups, networks and value chains. Central and local governments periodically tally votes of the populations, collect taxes, and maintain property registries, enabling the creation of public institutions that redistribute wealth and maintain order. Centralized legislative and judiciary systems elaborate institutional laws and resolve potential disputes between public, private and hybrid actors. ${ }^{1}$

What is remarkable, business entities as multinational enterprises are often even more centralized and powerful than political entities; for centuries, banks for example acted as central referees, keeping ledgers managing the inflow and outflows of wealth, and enabling intra- and transnational commerce and business to thrive despite of small and weak states. In pre-modern times great multinational companies as the Dutch and English East Indian Companies and in modern times centralized businesses, often in a transnational group form and organised as listed companies are on their behalf in charge of producing, aggregating, and distributing resources and services in value chains, generating substantial producer surpluses to their members. In order to obtain efficiency gains, these centralized organizations vertically and horizontally integrate, consolidating markets and generate enormous concentrations of power, often at the expense of the individuals and the planet. ${ }^{2}$

On the other hand, states themselves are active market actors, not only 'market-fixers' facilitating private value creation and redistributing it, but also - and especially - marketmakers and market-shapers. According to neoclassical economics, states fix market failures, especially public goods such as clean air or new knowledge arising from basic research, imperfect competition arising from natural monopolies, network effects and economies of scale, and negative externalities such as traffic congestion or climate change. States act also as active firms and investors co-create value in society in cooperation with private actors. The Chinese government is for instance today the largest global funder of green innovations. ${ }^{3}$ Innovation, in energy as in other sectors, requires patient, long-term, committed finance, which

\footnotetext{
${ }^{*}$ This Chapter is part of Sustainable Market Actors for Responsible Trade (SMART) research project, funded by the European Union under the Horizon 2020 programme, grant agreement 693642. The contents of this Chapter are the sole responsibility of the SMART project and do not necessarily reflect the views of the European Union.

1 Aaron Wright and Primavera De Filippi, 'Decentralized Blockchain Technology and the Rise of Lex Cryptographia' (March 10, 2015) $18<$ https://ssrn.com/abstract=2580664 > accessed 4 March 2018.

2 Wright and De Filippi, 'Decentralized Blockchain Technology' 18.

3 Mariana Mazzucato, 'The entrepreneurial state: socializing both risks and rewards' (2018) 84 real-world economics review 201.
} 
many private investors lack. Public sources of finance have a crucial role in setting up new markets through their early, risk-taking and patient direct investments rather than only through indirect public incentives supporting private investments. ${ }^{4}$

What is common, the public and private economic power concentrations are based on pathdependent techniques of corporate finance. In the beginning, an enterprise relies on equity financing from its founders. Founding entrepreneurs rely on their own savings but also their families' and friends'. These finances are governed by general corporation law for different business forms as partnerships, companies and cooperatives. Traditionally, in the centralized market structure applied for centuries, the second main source of financing has been debt financing. After Financial Crisis 2007-8 however bank financing has been harder and harder due to lacking tangible collaterals. Public development funds and banks have however taken a bigger role in startup financing too, not only financing matured enterprises.

If listed on regulated markets with an initial public offering, enterprises become dependent on new institutional organisations, investment supply chains consisting of public, private and hybrid institutional investors, ${ }^{5}$ as private and public pension funds and pension companies, mutual funds and hedge funds and their intermediaries as asset managers and proxy advisors. With their maturity listed firms are more interesting even for public market actors as sovereign wealth funds, national wealth funds, sovereign development funds and public pension reserve funds, as well as and private civil law foundations, that are major shareholders especially in North European listed companies. Recently, new hybrid public private partnership investment vehicles have emerged. ${ }^{6}$ This heterogeneity of investors and investment supply chains reflects investors' and their intermediaries' preferences and conflicting interests. Private equity investors have incentives to influence the firms' governance for long-term profit. Institutional investors are often more short-term oriented and passive. Public investors have both financial and non-financial public policy expectations, with mixed short-term and long-term profit demands.

Even more demanding financing is if a firm follows a sustainable business model, especially in circular economy. A transition to a sustainable circular economy entails four fundamental building blocks: (1) materials and product design, (2) new business models, (3) global reverse networks to recover either the product itself or its components and materials and (4) enabling conditions. ${ }^{7}$ A sustainable business model is crucial, how the demands of circular economy are

\footnotetext{
${ }^{4}$ Gregor Semieniuk and Mariana Mazzucato, 'Financing green growth', UCL Institute for Innovation and Public Purpose (IIPP) Working Paper IIPP WP 2018-04 (June 2018) <https://www.ucl.ac.uk/bartlett/publicpurpose/publications/2018/jun/financing-green-growth> accessed 26 June 2018.

5 By 'institutional investors', I mean institutions investing others' savings on their behalf ('money managers'). Typical institutional investors are public and private pension funds and companies, insurance companies and other joint investment properties as civil law foundations and sovereign wealth funds as well as hedge funds. See Edward B. Rock, 'Institutional Investors in Corporate Governance', University of Pennsylvania Institute for Law \& Economics Research Paper No. 1437 (July 21, 2015) 5 <http://ssrn.com/abstract=2512303> accessed 4 March 2018.

6 Douglas J. Cumming, Luca Grilli and Samuele Murtinu, 'Governmental and independent venture capital investments in Europe: A firm-level performance analysis' (2017) 42 Journal of Corporate Finance 439.

7 Patrick Planing, 'Business Model Innovation in a Circular Economy Reasons for Non-Acceptance of Circular Business Models' Open Journal of Business Model Innovation (April 2015, in press), 2; Patrick Planing, 'Towards a circular economy - how business model innovation will help to make the shift' (2018) 20 International Journal of Business and Globalisation 71, 72.
} 
applied in individual enterprises' businesses. ${ }^{8}$ A business model articulates how a firm converts resources and capabilities into economic value. It is the organisational and financial 'architecture' of a business' value creation, including implicit assumptions about customers, their needs, and the behaviour of revenues, costs and competitors. ${ }^{9} \mathrm{~A}$ ' $\mathrm{t}$ ] ruly sustainable business shifts its perspective from seeking to minimize its negative impacts to understanding how it can create a significant positive impact in critical and relevant areas for society and the planet.' 10 Truly sustainable business turns from 'inside-out' business model putting the shareholder interests first by maximising sales and distributable profits to 'outside-in' model based on the shared values of the firm and its stakeholders, seen typical for Nordic firms and 'social businesses' as cooperatives. ${ }^{11}$

A circular business model can be defined as '[t]he rationale of how an organization creates, delivers, and captures value with slowing, closing, or narrowing flows of the resource loops'.12 Shifting from a linear to a circular business model requires distribution planning, inventory management, production planning, and management of a reverse logistics network, a substantial amount of time but also investment on the part of the enterprise. ${ }^{13}$ Especially the upfront costs of 'green' investments emerged in the literature review as a significant barrier. ${ }^{14}$ To achieve a truly sustainable business model requires so also changes in financing. Modern short-term-based legal and financial systems that support 'take, make and waste' business models are not necessarily conducive to the new settings that sustainable value creation, for instance circular economy requires. ${ }^{15}$

Finance has indeed been identified one of the most important barriers for a circular business model. ${ }^{16}$ Explaining the lack of financing sustainable businesses typically invoke a 'twin market failure': on the one hand, part of the cost of polluting unsustainable 'brown' activities has not been properly internalized that gives them a cost advantage in an 'inside-out' businesses; on the other hand, the innovations required to develop alternative 'green' technologies and products are underfinanced because private investors cannot internalize the returns from their

\footnotetext{
8 Mateusz Lewandowski, 'Designing the Business Models for Circular Economy-Towards the Conceptual Framework' (2016) 8 Sustainability, 43, 2 <doi:10.3390/su8010043> accessed 4 March 2018.

9 David J. Teece, 'Business Models, Business Strategy and Innovation' (2010) 43 Long Range Planning 172; N.M.P. Bocken, S.W. Short, P. Rana and S. Evans, 'A literature and practice review to develop sustainable business model archetypes’ (2014) 65 Journal of Cleaner Production 42.

10 Thomas Dyllick and Katrin Muff, 'Clarifying the Meaning of Sustainable Business: Introducing a Typology From Business-as-Usual to True Business Sustainability' (2016) 29 Organization \& Environment 156, 165-6.

${ }^{11}$ Robert Strand, R. Edward Freeman and Kai Hockerts, 'Corporate Social Responsibility and Sustainability in Scandinavia: An Overview' (2015) 127 Journal of Business Ethics 1, 8; Dyllick and Muff, 'Clarifying', 166.

12 Pejvak Oghazi and Rana Mostaghel, 'Circular Business Model Challenges and Lessons Learned-An Industrial Perspective' (2018) 10 Sustainability 739, 3 <doi:10.3390/su10030739> accessed 4 March 2018.

13 Vasileios Rizos, Arno Behrens, Wytze van der Gaast, Erwin Hofman, Anastasia Ioannou, Terri Kafyeke, Alexandros Flamos, Roberto Rinaldi, Sotiris Papadelis, Martin Hirschnitz-Garbers and Corrado Topi, 'Implementation of Circular Economy Business Models by Small and Medium-Sized Enterprises (SMEs): Barriers and Enablers' (2016) 8 Sustainability 1212, 3, <doi:10.3390/su8111212> accessed 4 March 2018.

${ }^{14}$ Rizos, Behrens, Kafyeke, Hirschnitz-Garbers and Ioannou, 'The Circular Economy'.

15 On circular economy see Martin Geissdoerfer, Paulo Savaget, Nancy M.P. Bocken and, Erik Jan Hultink, 'The Circular Economy - A new sustainability paradigm?' (2017) 143 Journal of Cleaner Production 757; Riina Antikainen, David Lazarevic, and Jyri Seppälä, 'Chapter 7: Circular Economy: Origins and Future Orientations' in Harry Lehmann (ed) Factor X: Challenges, Implementation Strategies and Examples for a Sustainable Use of Natural Resources (Springer 2018) 115.

16 Vasileios Rizos, Arno Behrens, Terri Kafyeke, Martin Hirschnitz-Garbers and Anastasia Ioannou, 'The Circular Economy: Barriers and Opportunities for SMEs' (September 17, 2015), CEPS Working Documents <https://ssrn.com/abstract=2664489 > accessed 4 March 2018.
} 
investments in sustainable businesses. ${ }^{17}$ Long-term sustainable business faces short-termism on investors and investments. The problem is emphasised in small and medium-sized enterprises and startups, recognised as drivers for circular economy. ${ }^{18}$ The finance gap is always worse with the small and medium-sized and 'social' enterprises than with larger forprofit companies but even worse it is in circular economy as it is capital intensive, has a high technology risk profile and uncertain exit opportunities for investors.

Albeit entrepreneurship is recognised as a major conduit for sustainable products and processes, ${ }^{19}$ and new ventures are viewed as an answer to many social and environmental problems, the role of venture capital is not unproblematic either. As an important catalyst to develop sustainable businesses, ${ }^{20}$ the payback (exit) horizon venture capitalists seek might be too short for sustainable investing. Startups in sustainable and circular economy lack the high growth and relatively fast exit horizons required before initial public offering or merger and acquisition. Listing of equity and bonds is challenging for circular economy business models as they require track record, size and maturity meeting the scale and requirements of capital markets and institutional investors.

One solution is sustainable bank and public engagement with less stringent financial constraints. ${ }^{21}$ However, even in countries where extensive 'green finance' is available, for instance from public and hybrid venture and development investment sources, gaps can occur when there is after startup phase only limited 'follow on' funding for businesses as they grow towards established commercialisation. ${ }^{22} \mathrm{New}$ solutions is so needed. Albeit 'near banks' like Google, Apple and Amazon platforms provide promising new payment facilities and working capital solutions for circular economy startups, the most promising vehicles for circular economy business models are crowdfunding ${ }^{23}$ and other peer to peer cooperative financing,

\footnotetext{
17 Adam B. Jaffe, Richard G. Newell and Robert N. Stavins, 'A tale of two market failures: Technology and environmental policy' (2005) 54 Ecological Economics 164; Gregor Semieniuk and Mariana Mazzucato, 'Financing green growth', UCL Institute for Innovation and Public Purpose (IIPP) Working Paper IIPP WP 2018-04 (June 2018), <https://www.ucl.ac.uk/bartlett/public-purpose/publications/2018/jun/financing-green-growth> accessed in 30 June 2018.

18 Tuuli Kaskinen, Satu Lähteenoja, Mikael Sokero, and Iiris Suomela, 'Chapter 22: Strategic Business Examples from Finland: The Growth of the Smartup Industry' in Harry Lehmann (ed) Factor X: Challenges, Implementation Strategies and Examples for a Sustainable Use of Natural Resources (Springer 2018) 325.

19 Jeremy K. Hall, Gregory A. Daneke and Michael J. Lenox, 'Sustainable development and entrepreneurship: Past contributions and future directions' (2010) 25 Journal of Business Venturing 439.

${ }^{20}$ N.M.P. Bocken, 'Sustainable venture capital - catalyst for sustainable start-up success?' (2015) 108 Journal of Cleaner Production 647.

21 Kerstin Lopatta, Reemda Jaeschke, Felix Canitz and Thomas Kaspereit, 'International Evidence on the Relationship between Insider and Bank Ownership and CSR Performance' (2017) 25 Corporate Governance: An International Review 41, 43; Kerstin Lopatta, Reemda Jaeschke and Chen Chen, 'Stakeholder Engagement and Corporate Social Responsibility (CSR) Performance: International Evidence' (2017) 24 Corporate Social Responsibility and Environmental Management 199.

22 Robyn Owen, Geraldine Brennan and Fergus Lyon, 'Enabling investment for the transition to a low carbon economy: government policy to finance early stage green innovation' (2018) 31 Current Opinion in Environmental Sustainability $137,138$.

23 On crowdfunding, see Ajay Agrawal, Christian Catalini, and Avi Goldfarb, 'Some Simple Economics of Crowdfunding' (2014) 14 Innovation Policy and the Economy 63. On crowdfunding and sustainability, see Jacob Hörisch, 'Crowdfunding for environmental ventures: an empirical analysis of the influence of environmental orientation on the success of crowdfunding initiatives' (2015) 107 Journal of Cleaner Production, 636; Nir Vulkan, Thomas Åstebro and Manuel Fernandez Sierra, 'Equity crowdfunding: A new phenomena' (2016) 5 Journal of Business Venturing Insights 37; Helen Toxopeus and Karen Maas, 'Crowdfunding Sustainable Enterprises as a Form of Collective Action' in Thomas Walker, Stéfanie D. Kibsey and Rohan Crichton (eds) Designing a Sustainable Financial System: Development Goals and Socio-Ecological Responsibility (Palgrave Macmillan 2018$) 263$.
} 
bringing a 'social' and 'engagement' element to financing, to solve the potential conflict between investors and other stakeholders.

Several circular economy enterprises have successfully used crowdfunding campaigns to acquire funds, which also helped them increase awareness about their product. 24 Crowdfunding allows entrepreneurs to raise funding from individuals and groups through an open call on the Internet; in crowdfunding an entrepreneur raises external financing from a relatively large audience (the 'crowd') in which each investor provides a relatively small amount, instead of soliciting a small group of sophisticated investors, without standard financial intermediaries. ${ }^{25}$

There are two basic forms of crowdfunding: entrepreneurs either solicit individuals to pre-order a product or service, or to advance a fixed amount of money in exchange for a share of future profits or equity. ${ }^{26}$ The pre-ordering scheme enables the entrepreneur to price discriminate between two groups of consumers, crowdfunders who pre-purchase the product, and 'regular' consumers, who wait until the product reaches the market. In profit sharing scheme entrepreneurs solicit individuals to provide money in exchange for a share of future profits or equity securities. Both schemes are associated with community-based experiences that generate 'community benefits' for participants, either consumption experiences or investment experiences, either sequentially or simultaneously. ${ }^{27}$

In some cases, crowdfunding in the profit-sharing mechanism resembles donations. This occurs when crowdfunders finance the project without sharing the profits with the entrepreneur. Donors might expect to become future consumers and community benefits are large, or they may support a project by donating money so that the entrepreneur can carry the project forward. Crowdfunders donate because they expect to be consumers or enjoy sufficient community benefits. ${ }^{28}$

A cooperative is a firm in which its members are the bearers of specific transactions toward the firm. ${ }^{29}$ It is 'collectively owned' usually either by its customers (a consumer cooperative) or by its suppliers (a producer cooperative as a workers' cooperative or an agrifood cooperative), or both (a multi-stakeholder cooperative). What is important in a cooperative is its particular kind of proprietorship model bound to the transaction-specific membership; ${ }^{30}$ profits in a cooperative are commonly allocated to the organization's 'patron owners' in proportion to the volume of their patronage (the amount they purchase from the organization in a consumer cooperative or sell to the organization in a producer cooperative), while control (commonly in the form of voting rights for election of the organization's board members) is commonly allocated either according to patronage or simply as one member one vote. For instance in a

\footnotetext{
${ }^{24}$ Rizos, Behrens, Kafyeke, Hirschnitz-Garbers and Ioannou, 'The Circular Economy'.

${ }^{25}$ Hörisch, 'Crowdfunding', 637; Paul Belleflamme, Thomas Lambert and Armin Schwienbacher, 'Crowdfunding: Tapping the right crowd' (2014) 29 Journal of Business Venturing 585.

26 Belleflamme, Lambert and Schwienbacher, 'Crowdfunding' 586.

27 Belleflamme, Lambert and Schwienbacher, 'Crowdfunding' 586.

28 Belleflamme, Lambert and Schwienbacher, 'Crowdfunding' 587.

29 See Stefano Zambon and Luca Zan, 'Accounting relativism: the unstable relationship between income measurement and theories of the firm' (2000) 25 Accounting, Organizations and Society 799, 810.

30 Zambon and Zan, 'Accounting relativism' 811.
} 
workers' cooperative, profits are generally allocated according to the value of the labour each worker-member-owner contributes to the organization, and votes are allocated the same way or per capita. ${ }^{31}$

Both crowdfunding and cooperative affect directly to the participants' behaviour by strengthening an open, transparent and interactive business model, engaging a high number of user participation and commitment, emphasising community aspects and limiting the access of profit and takeover seeking investors. Crowdfunding is increasingly popular to create funds for projects in which financial institutions are not investing. A cooperative is a peer to peer financing model hard to disrupt by takeovers. Cooperative gives also the users a unique possibility to own market places themselves.

Crowdfunding and cooperative are not however unproblematic as financing schemes of sustainable business models. Crowdfunding scene is dominated by commercial for-profit intermediaries, the platforms, often raising doubts of their own sustainability, ${ }^{32}$ and so affecting the sustainability of the target businesses themselves. As far as cooperatives are concerned, how ever they are strengthening social cohesion and 'democracy' issues between the members as such, they also tend to ignore the financial, social (human) and environmental negative externalities they cause. ${ }^{33}$ Following the competitive logic and the interests of their own members only and not the society as a whole, cooperatives eventually start behaving in very similar ways than for profit companies. ${ }^{34}$

In this Chapter, crowdfunding and cooperatives are compared to analyse what kind of dynamics are crucial to overwhelm these obstacles for a successful sustainable circular economy financing, to serve an enterprise trying to achieve a sustainable business model. Specific attention is given to the drivers that increase the investors' commitment for long-term circular economy-based behaviour. What makes a cooperative approach especially important is its social dimension, often ignored in circular economy discussion, albeit crucial to sustainable development-based on intra- and intergenerational equity. Circular economy does not mean only an economic model wherein planning, resourcing, procurement, production and reprocessing are designed and managed, as both process and output, to maximize ecosystem functioning but also human wellbeing. ${ }^{35}$

\footnotetext{
${ }^{31}$ Henry Hansmann, 'All firms are cooperatives - and so are governments' (2013) 2 Journal of Enterpreneurial and Organizational Diversity 1, 1.

32 Javier Ramos, 'Crowdfunding and the Role of Managers in Ensuring the Sustainability of Crowdfunding Platforms' in James Stewart (ed) European Commission Joint Research Centre Scientific and Policy Reports (Seville, 2014) 63, <ftp://ftp.jrc.es/pub/EURdoc/JRC85752.pdf> accessed 4 March 2018.

33 Raquel Ajates Gonzalez, 'Going back to go forwards? From multi-stakeholder cooperatives to Open Cooperatives in food and farming' (2017) 53 Journal of Rural Studies 278, 283. For instance in agri-food, farmers face financial externalities by their diminishing share of food profits, employees social externalities by diminishing salaries and the whole planet faces environmental costs by agri-food business endangering the planetary boundaries.

${ }^{34}$ Ajates Gonzalez, 'Going back', 280, referring to Michel Bauwens in Stacco Troncoso, 'Michel Bauwens on the Rise of Multi-stakeholder Cooperatives' (November 13, 2014), P2P Foundation, <https://blog.p2pfoundation.net/michel-bauwens-on-the-rise-of-multi-stakeholder-cooperatives/2014/11/13> accessed 4 March 2018.

${ }^{35}$ Alan Murray, Keith Skene and Kathryn Haynes, 'The Circular Economy: An Interdisciplinary Exploration of the Concept and Application in a Global Context' (2017) 140 Journal of Business Ethics 369.
} 


\section{Finance as the path to unsustainability}

When an entrepreneur starts her business (what I call in this Chapter as a 'productive firm' to make a difference between these target firms and the 'financial firms' that invest in them, as banks and other institutional investors as pension funds ${ }^{36}$ ) it is understandable she thinks the business is hers. She invests her personal savings and other capitals. However, often that is not enough and she needs other investors, firstly her family and friends and maybe her first recruits. With new investors, especially if she leans on creditors from whom she takes a debt for the firm on its behalf, her ownership to the firm become more and more relative. She must share her decision-making powers with the other equity investors, and the creditors, employees included, have factual power over the firm due to their bargaining power. In the need of more capital she might turn to other investors providing private equity and venture capital of fund managers investing in startups in growth stage on behalf of their limited partners, 'accelerators' and 'angels' (individual rich persons aiming at high returns from early stage ventures), for instance. Equity is important as new companies have always suffered shortage of financing because financial firms as commercial banks cannot lend to firms lacking collateral assets and revenues, nor can the firms pay the high fees and retainers demanded by traditional investment banks and law firms. ${ }^{37}$

After listing to regulated securities markets through an initial public offering, the situation of productive firms obfuscates dramatically. With listing, two new types of investors are introduced: the active marginal traders who set the market prices, often using algorithmic trading, and the institutional investors who invest other people's moneys on their behalf. Neither of these investor groups are 'shareholders' in the traditional sense. The modern capital markets are ruled by these intermediaries in extended chains of investment, in which individual ultimate beneficiaries (as customers of pension funds and hedge funds), the institutional investors managing their moneys, and the productive firms in which the institutional investors invest, are separated. This investment supply chain 38 system strengthens the influence of institutional investors and other investment intermediaries, since the ultimate beneficiaries as future pensioners investing either voluntarily or involuntarily their savings in pension funds cannot directly influence the practices of firms in which they invest. $^{39}$

Due to the investment supply chain complexity, financial intermediaries have become in the centre of corporate ownership and debate. It is these intermediaries, or to be exact not them but their 'money managers', not their ultimate beneficiaries or the board members of the productive companies as before, who determine how their capital is put to work and how the mountain of shares owned for their benefit is used to influence the management of listed

\footnotetext{
36 The dichotomy managers of productive corporations - money managers is used for instance in Strine, 'Can We Do Better' Leo E. Strine, Jr., 'Can We Do Better by Ordinary Investors? A Pragmatic Reaction to the Dueling Ideological Mythologists of Corporate Law' (2014) 114 Columbia Law Review 449, 451.

37 'Reinventing the deal: America's startups are changing what it means to own a company', The Economist, Oct 24th 2015, from the print edition <http://www.economist.com/news/briefing/21676760-americas-startupsare-changing-what-it-means-own-company-reinventing-deal> accessed 4 March 2018; Patrick T.I. Lam and Angel O.K. Law, 'Crowdfunding for renewable and sustainable energy projects: An exploratory case study approach' (2016) 60 Renewable and Sustainable Energy Reviews 11, 12.

38 Wendy Stubbs and Colin Higgins, 'Stakeholders' Perspectives on the Role of Regulatory Reform in Integrated Reporting' (2018) 147 Journal of Business Ethics 489, 496.

${ }^{39}$ Virginia Harper Ho, 'Risk-Related Activism: The Business Case for Monitoring Nonfinancial Risk' (2015) 47 The Journal of Corporate Law 647, 677.
} 
companies. Given the directional momentum of public policy in the US and Europe, the inflow of funds from forced capitalists to these intermediaries is likely to continue to increase ${ }^{40}$ Fund managers have to deal with an ever-growing group of intermediaries, from regulators to their own employees, and each layer has its own interests to serve and rents to extract. No wonder fund managers usually fail to monitor individual companies. ${ }^{41}$

However, although markets sometimes look to the long-term, many managers feel that their jobs depend upon producing good short-term results, quarter after quarter. ${ }^{42}$ There is no change in the behaviour patterns of either institutional investors or board members. However, all these conflicting interests, short-termism and regulation impose costs. Because money managers reductively focus on equity returns, they blind themselves to any consideration of externality effects or the larger economic outcomes of the economy for its citizens. ${ }^{43}$ In this environment, investments themselves are short sighted: for instance in the United States, the shareholder base of public companies turns over almost completely on annual basis. ${ }^{44}$ This short-term nature of investments undermines the possible differences in institutional shareholders' investment horizons. So, although some institutional investors as pension funds might have longer term investment horizons compared to mutual funds, supporting in principle sustainable investments, ${ }^{45}$ this plays no role in the end of the day.

So, after a century of utter dominance, the public listed company is showing signs of wear and it is no surprise that new solutions to finance business are looked for to strengthen entrepreneurship, 'ownership' and long-term sustainable value creation, instead of long investment supply chains of financial intermediaries losing their focus, loss of commitment and short-termism. There is not however one size that fits all, but several new insights to financing that complement each other. As one example besides crowdfunding and new cooperatives can be mentioned the new Silicon Valley model of capitalism practised by startups, as an attempt to get around the inefficiencies and costs imposed by the multi layered agency problems caused by complicated investment supply chains. ${ }^{46}$ The central difference between traditional investment supply chains and its alternatives lies however always in ownership: whereas due to the chain of intermediaries using complicated financial instruments as share lending nobody is sure who owns and uses power in public listed companies, new startups go to great lengths to define who 'owns' what. ${ }^{47}$ To add, it is no accident that while public companies are in a crisis, other corporate organizations are on the rise. They might even be the answer to the problem of corporate sustainability. In the following sections new insights are given to financing sustainable businesses, using circular economy as an example.

\footnotetext{
40 Strine, 'Toward Common Sense' 4-5.

41 'Reinventing the company'.

42 'Reinventing the company'.

43 Strine, 'Can We Do Better' 461.

${ }^{44}$ Leo E. Strine, Jr., 'One Fundamental Corporate Governance Question We Face: Can Corporations Be Managed for the Long Term Unless Their Powerful Electorates Also Act and Think Long Term?' (2010) 66 The Business Lawyer $1,17$.

45 Tanusree Jain and Dima Jamali, Looking Inside the Black Box: The Effect of Corporate Governance on Corporate Social Responsibility (2016) 24 Corporate Governance: An International Review 253, 260.

46 'Reinventing the deal'.

47 'Reinventing the company: Entrepreneurs are redesigning the basic building block of capitalism', The Economist, Oct 24th 2015, from the print edition <http://www.economist.com/news/leaders/21676767-entrepreneurs-areredesigning-basic-building-block-capitalism-reinventing-company?frsc=dg\%7Cd> accessed 4 March 2018.
} 


\section{Financing circular economy}

\subsection{Opening the door}

The new corporate forms take many forms. What is common for them is to solve the problem of conflicting interests, short-termism and regulation that impose costs to listed firms, 'to tap into public markets while remaining closely held.' 48 What is essential is the business model, 'the organizational and financial 'architecture' of a business'. ${ }^{49}$

As before, also new startups typically begin with savings, or money from family and friends, but then they tap outside private, public and hybrid investors for seed funding through a variety of channels, including lawyers, accelerators (in essence, schools for startups) and other 'angel' investors with cash to back founders with ideas. These increasingly include entrepreneurs who made money from their own startups and now invest in others. ${ }^{50}$ It is from this basic model the differences to the past however start.

Firstly, new generation of family companies and startups have a new lease of life. Their new corporate culture is an attempt to answer to the problems of traditional companies' life span, either traditional closed or listed ones. It is a counter reaction to the demise of the listed company and forced capitalism in which the financial instruments are 'decoupled' using share lending and other financial engineering mechanisms separating economic rights associated to a share the company has issued from voting rights attached by the company to it. ${ }^{51}$ For the new startups, (re)coupling between ownership and responsibility is typical: investors do not want any more deconstruct their equity investments but want to exert control (again) directly. ${ }^{52} \mathrm{At}$ the same time new startups are however reaching pools of capital that neither an old fashioned family business nor a listed company would have got their hands on. One example is 'sustainable venture capitalists' who balance financial against social and environmental returns when investing in sustainable startups, seeking to prove new investment formats and demonstrate that sustainable business is good business. ${ }^{53}$ What is important, they are contractbased instead of regulation-based as the traditional business models, based on transparency and agency, building their finance to direct contracting on the rights and responsibilities of the firm members without intermediaries.

Secondly, the role of public market actions in financing is taking new forms. ${ }^{54}$ New types of governmental venture capital funds ${ }^{55}$ as upside down public wealth funds, investment management entities consisting of private equity funds the management entity is a general partner, are emerging, calling for private investors as limited partners, are penetrating the private equity and venture capital markets, instead of traditional sovereign wealth funds

\footnotetext{
48 'Reinventing the company'.

49 David J. Teece, 'Explicating dynamic capabilities: the nature and microfoundations of (sustainable) enterprise performance' (2007) 28 Strategic Management Journal 1319, 1329.

50 'Reinventing the deal'; Bocken, 'Sustainable venture capital' 648.

${ }^{51}$ Henry T.C. Hu \& Bernard Black, 'The New Vote Buying: Empty Voting and Hidden (Morphable) Ownership' (2006) 79 Southern California Law Review 811; Wolf-Georg Ringe, 'Hedge Funds and Risk Decoupling: The Empty Voting Problem in the European Union' (2013) 36 Seattle University Law Review 1027, especially p. 1030-1031.

52 'Reinventing the company'.

53 Bocken, 'Sustainable venture capital' 656.

54 As examples from both developed and emerging economies, see Owen, Brennan and Lyon, 'Enabling investment'.

${ }^{55}$ Cumming, Grilli and Murtinu, 'Governmental and independent venture capital'.
} 
investing public funds on private listed equity and real estate, without socializing the risk. ${ }^{56}$ Venture capital funds can however open the path even for them to private equity. ${ }^{5}$

With contractual-based corporate arrangements, a new experience of 'ownership' is (re)provided in firms that sidesteps the 'agency' concerns of listed companies, simultaneously by avoiding the contentious regulations and politics that surround listed business. ${ }^{58}$ Being private, the new business models are free of the chains of complex financial reporting standards as the United States Generally Accepted Accounting Principles or the International Financial Reporting Standards, enabling instead of their standards own tailored performance-based indicators. 59

\subsection{Entering sustainability}

All new startup business models are not necessarily sustainable, of course. What is crucial is sustainable entrepreneurship, a business model pursuing simultaneously economic, social and ecological goals. According to Belz and Binder, a sustainable entrepreneurship includes six phases: (1) recognizing a social or ecological problem; (2) recognising a social or ecological opportunity; (3) developing a double bottom line solution; (4) developing a triple bottom line solution; (5) funding and forming of a sustainable enterprise; and (6) creating or entering a sustainable market. ${ }^{60}$ Lack of funding has been recognized as a central obstacle hindering sustainable development and entrepreneurship. There is a fundamental difference between conventional investors and environmental entrepreneurs. As pointed by Hörisch, many sustainable entrepreneurs lack business education and experience, focusing to the environmental impact of their business without sufficiently considering its financial aspects or lacking competence to successfully communicate with financiers. ${ }^{61}$

On the other hand, as far as funding a sustainable enterprise is concerned, there is no one standard financing model. Sustainable 'seed capital' can still be personal assets from the founders and their families and friends, but also aid from a public or hybrid entity as the new sovereign venture capital funds, a debt from a more traditional sovereign development bank or fund or rounds of crowdfunding. 62 The social and environmental good of sustainable enterprises opens up the door to public funding and new unconventional forms of funding, such as crowdfunding. ${ }^{63}$ Especially crowdfunding has been seen as a promising alternative means to finance sustainability oriented ventures and especially clean production technologies. ${ }^{64}$ Another even more specific alternative is using a crowdfunded cooperative to develop an open, transparent and interactive business model, to engage a high number of user participation and

\footnotetext{
${ }^{56}$ As US examples, see Steven M. Davidoff, 'Uncomfortable Embrace: Federal Corporate Ownership in the Midst of the Financial Crisis' (2011) 95 Minnesota Law Review 1733; Robert C. Hockett and Saule T. Omarova, 'Public Actors in Private Markets: Toward a Developmental Finance State' (2015) 93 Washington University Law Review 103, 154-160.

57 Diego Lopez, 'The Rise of Sovereign Venture Funds' in Bernardo Bortolotti (ed.) The Sky Did Not Fall: Sovereign Wealth Fund Annual Report 2015 (Milan: Sovereign Investment Lab, 2016) 61.

$58^{\prime}$ Reinventing the deal'.

59 'Reinventing the company'.

${ }^{60}$ Frank Martin Belz and Julia Katharina Binder, 'Sustainable Entrepreneurship: A Convergent Process Model' (2017) 26 Business Strategy and the Environment 1, 1.

61 Hörisch, 'Crowdfunding', 637.

62 Belz and Binder, 'Sustainable Entrepreneurship' 8-9.

63 Belz and Binder, 'Sustainable Entrepreneurship' 16.

${ }^{64}$ Hörisch, 'Crowdfunding' 637.
} 
limit the access of major investors. ${ }^{65} \mathrm{~A}$ cooperative is a business model hard to disrupt by takeovers. Cooperative gives also the users a unique possibility to own market places themselves. In the following, special interest is given to this kind of sustainable crowdfunded and cooperativist business models in a circular economy environment.

\section{Crowdfunding}

The problem of traditional start up model is in its short-termism: private equity providers wait for their opportunity to cash out their investment through an initial public offering.

Public markets are seen not any more as a place to raise money and create long-term enterprises than as a mechanism to cash out if and when the time is right. One way how to try tackle this problem is crowdfunding. Startups have been a long time able to get initial equity capital at effectively no cost from crowdfunding online platform sites like Kickstarter and Indiegogo. An enthusiastic reception can attract bigger investors in a conventional way. This was the route taken by Oculus VR, a virtual reality startup acquired in 2014 by Facebook for USD 2 billion. ${ }^{66}$ In circular business models, Fairphone, the social enterprise that produce smartphones maximising the social impact in all stages of the value chain from sourcing and production to design and recycling, used crowdfunding to raise awareness about its product and to inform consumers about its process of producing consumer electronics, managed to receive 10,000 pre orders for its first smartphone during a one month crowdfunding campaign, which enabled the company to then produce the phone on a larger scale and eventually sell around 60,000 devices. ${ }^{67}$

Crowdfunding can be also publicly supported. For instance the United Kingdom government has facilitated crowdfunding through regulatory and tax support, enabling establishment of the pioneering Crowdcube and Seedrs early stage equity platforms. It has also provided guarantees to support peer to peer lending through the Zopa and Funding Circle platforms. ${ }^{68}$ One example of crowdfunding is as in Germany to support early stage renewable and sustainable energy projects requiring finance incentive advanced technology. ${ }^{69}$ There has also been a growing interest in community shares for community owned renewable energy projects, with innovative organisational models but using previously developed technology. ${ }^{70}$ Crowdfunding effectively compresses the startup process, enabling the starting entrepreneur to jump directly to contacting the potential customers and determining if they would be interested in the concept. As more and more businesses are now conducted online, it can be expected that there will be even more dramatic and speedier changes in business models and value chains in the years to come. ${ }^{71}$

\footnotetext{
65 Belz and Binder, 'Sustainable Entrepreneurship' 9.

66 'Reinventing the deal'.

${ }^{67}$ Rizos, Behrens, Kafyeke, Hirschnitz-Garbers and Ioannou, 'The Circular Economy'.

${ }^{68}$ Owen, Brennan and Lyon, 'Enabling investment' 140.

${ }^{69}$ Lars Holstenkamp and Franziska Kahla, 'What are community energy companies trying to accomplish? An empirical investigation of investment motives in the German case' (2016) 97 Energy Policy, 112, 114; Lam and Law, 'Crowdfunging'; Owen, Brennan and Lyon, 'Enabling investment' 140.

70 Owen, Brennan and Lyon, 'Enabling investment' 140.

${ }^{71}$ Mark Esposito and Terence Tse, 'DRIVE: The Five Megatrends that Underpin the Future Business, Social, and Economic Landscapes' (2018) 61 Thunderbird International Business Review 121, 127.
} 
More demanding than short-term initial funding is long-term crowdfunding equity financing. Crowdfunding includes an inherent agency problem if the organisation's 'agents' (board and managers) do not have the ability to identify the agency problem between themselves and the numerous capital providers, remaining vulnerable to the risk of mismanagement from these faceless principals. ${ }^{72}$ To tackle agency problem as this, the standard solution is to use intermediaries. In crowdfunding, the platforms act as intermediaries: ordinary people can invest in startups on long-term basis directly through platforms such as SeedInvest or indirectly through mainstream mutual funds such as T. Rowe Price, ${ }^{73}$ which buys into them during their infancy. ${ }^{74}$

Let's take as an example sustainable agrifood. 'Alternative' food movements have challenged the conventional capitalist food system, regarded as environmentally unsustainable, socially unjust and economically over centralized. From the 1990s an alternative system of food provision, labelled as Alternative Food Networks has been prefigured in initiatives that aim to reconcile production with nature and reconnect producers to consumers. ${ }^{75}$ During the last years, even growing number of farmers has turned to support sustainable agriculture projects. ${ }^{76}$

Crowdfunding gives people the opportunity to support small, local, family farms in a tangible way and so to a possibility for a producer-nonproducer multi-stakeholder collaboration, unknown before to for instance cooperatives strictly divided between even hostile producer cooperatives and consumer cooperatives. ${ }^{77}$ Traditional corporate finance forms are challenging to agrifood startups. On the other hand, neither conventional venture capital and private equity nor debt financing guarantees customer support. Sustainable agrifood has the potential to completely reshape global agriculture, dramatically increasing the productivity of the agriculture system while reducing the environmental and social costs of current production practices. There has been however relatively little investment in sustainable agrifood compared to other lifecycle-based industries. Crowdfunding platforms such as Kickstarter, Indiegogo, Barnraiser and GoFundMe allow creators to post profiles of their projects online and seek funding from backers to bring the projects to life. More than USD 34 billion in financing was raised through crowdfunding in 2015 via 1,250 active crowdfunding platforms worldwide. ${ }^{78}$

The basic idea of crowdfunding is to bring direct customer support into the business model. There are, however, obstacles that prevent efficient crowdfunding-based corporate finance. A main problem is the role of platforms as intermediaries. In spite of their more decentralised flavour in comparison to more traditional funding models, most crowdfunding endeavours are coordinated and regulated by large platform intermediaries as trusted third party responsible for collecting and redistributing the funds. The rules, technical features, and cultural norms

\footnotetext{
72 Mehar, Shier, Giambattista, Gong, Fletcher, Sanayhie, Kim and Laskowski, 'Understanding'.

73 See https://www3.troweprice.com/usis/corporate/en/home.html> accessed 4 March 2018.

74 'Reinventing the company'.

${ }^{75}$ Maria Fonte and Ivan Cucco, 'Cooperatives and alternative food networks in Italy. The long road towards a social economy in agriculture', (2017) 53 Journal of Rural Studies 291, 292.

${ }^{76}$ Jodi Helmer, 'Herdfunding: how the internet is raising money for farms: Instead of approaching banks, small, local farms are finding cash and loyal fans online', The Guardian (29 April 2016) <https://www.theguardian.com/sustainable-business/2016/apr/19/crowdfunding-internet-raising-moneyfarm-finance> accessed 4 March 2018.

77 Fonte and Cucco, 'Cooperatives' 292.

${ }^{78}$ Helmer, 'Herdfunding'.
} 
established by individual platforms shape the behaviour of creators and funders and ultimately determine the extent to which the market for crowdfunding operates efficiently. ${ }^{79}$ The majority of these crowdfunding platforms only operates on top of the traditional financing mechanisms. Intermediaries such as banks and payment service providers represent an integral part of the crowdfunding ecosystem and are responsible for the processing of financial transactions. Thus, the current ecosystem heavily relies on trusted third parties with a platform failure risk. ${ }^{80}$

Due to lack of investor and consumer protection, a new information asymmetry is created unknown to consumers accustomed to traditional consumer protection and product liability regulation, while the platforms are only intermediaries without a responsibility towards either innovators or investors. The answer might be in crowdfunder-entrepreneur-owned platforms themselves, organized as multi-stakeholder cooperatives themselves.

\section{New cooperatives}

It is clear that the roots of crowdfunding itself are in cooperatives; both are collective efforts by people networking and pooling their money together for a common goal, as Internet and especially social media has given boost to crowdfunding, it also enables new forms of cooperativism. ${ }^{81}$ When comparing pre ordering scheme and profit sharing crowdfunding schemes, the investors in the latter may or may not decide to become customers at a later stage. If they commit to being customers, we are in the matter of fact back again in a cooperative style crowdfunding. Crowdfunding is cooperativism as crowdfunding as such requires close cooperation between the participating entrepreneurs, crowdfunders) and possible intermediaries (crowdfunding platforms). Each party has a 'mission' that brings them together to achieve a commonly desired goal. ${ }^{82}$

Regulation might strengthen cooperativism in crowdfunding. Due securities markets regulation profit sharing crowdfunding can be problematic if it involves public offering of equity to the crowd. For instance in the United States general solicitation for equity offering was limited to publicly listed equity until the 2012 Jumpstart Our Business Startups Act ${ }^{83}$ (JOBS Act) legalising equity-based crowdfunding. Jurisdictions may also limit how many private investors an enterprise can have. ${ }^{84}$ Therefore, most profit sharing initiatives do not offer shares in limited liability companies but provide other types of rewards, such as a product or membership with voting rights, benefits typical for a cooperative. Cooperative is an open, transparent and interactive business model, and as such suitable for a sustainable enterprise, engaging a high number of users and limit the access of major investors. ${ }^{85}$

\footnotetext{
${ }^{79}$ Agrawal, Catalini, and Goldfarb, 'Some Simple Economics' 79.

80 Philipp Haas and Ivo Blom, 'Blueprinting Crowdfunding - Designing a Crowdfunding Service Configuration Framework', in Wirtschaftsinformatik Konferenz (WI) 2017, St. Gallen, Switzerland < https://www.alexandria.unisg.ch/249862/> accessed 4 March 2018; André Schweizer, Vincent Schlatt, Nils Urbach and Gilbert Fridgen, Unchaining Social Businesses : Blockchain as the Basic Technology of a Crowdlending Platform, 38th International Conference on Information Systems (ICIS), 10.-13.12.2017, Seoul, South Korea <https://eref.uni-bayreuth.de/39743/> accessed 4 March 2018.

81 See E. Vasileiadou, J.C.C.M. Huijben and R.P.J.M. Raven, 'Three is a crowd? Exploring the potential of crowdfunding for renewable energy in the Netherlands' (2016) 128 Journal of Cleaner Production $142,142$.

82 Lam and Law, 'Crowdfunding' 12.

83112 P.L. 106, 126 Stat. 306.

${ }^{84}$ Belleflamme, Lambert and Schwienbacher, 'Crowdfunding' 588.

85 Belz and Binder, 'Sustainable Enterpreneurship' 9.
} 
As an example of circular economy crowdfunding like cooperatives can be mentioned renewable energy production in 'community energy' in which individuals jointly invest in and operate renewable energy installations. Cooperative form allows an investment that is tolerable for private individuals. At the same time the legal status of a cooperative reflects a 'democratic' approach: every member has a vote irrespective of her investment sum. ${ }^{86}$ In community energy cooperatives, energy security can be maintained by giving communities control of the energy they use. Cooperative members can share the dividends from energy sell profits in proportion to their investments and democratic management can be exercised with each member having one vote. ${ }^{87}$

The challenge of traditional cooperatives has been however the lack of shared fundamental values between different groups of producer members, as well as between producers and nonproducers, producer cooperatives and consumer cooperatives, as for example agricultural cooperative organizations seem to be driven by economic strategies of consolidation and competition in the national and global markets, 'clinging ... to an economic paradigm functional to the neoliberal ideology of globalization, instead social and environmental sustainability'. ${ }^{8} 8$ The situation has been worsening all the time as the farmers get an increasingly small piece of the pie of food profits. ${ }^{89}$

However, there are promising new cooperatives for instance in the Netherlands in which farmers and nonfarmers work in close collaboration to integrate nature management into farming practices in joint environmental projects. Generally, new 'food movements' tend to renew the cooperative movement and strengthen its ideological basis and social motivations, connecting it to critical consumption, sharing economy, peer to peer production, transition towns and in general 'new movements reclaiming a sustainable economy-based on three pillars of sustainability'. ${ }^{90}$ In new multi-stakeholder cooperatives ${ }^{91}$ producers, workers, consumers and restaurateurs cooperate in one single enterprise to create a sustainable value chain between rural and urban areas and to overcome the limitations of conventional supply chaincentred farmer cooperatives focused more on economic than social and environmental benefits. ${ }^{92}$ The Quebec law recognises solidarity cooperatives, a hybrid form of cooperative enterprise that allows for up to three types of membership; user members, worker members, and supporting members who has an economic, social or cultural interest in the pursuit of the objects of the cooperative. Supporting membership provides the cooperative added versatility

\footnotetext{
${ }^{86}$ Holstenkamp and Kahla, 'What are community energy companies', 115; Law and Law, 'Crowdfunding', 18.

87 Law and Law, 'Crowdfunding' 18.

88 Fonte and Cucco, 'Cooperatives' 292, 293.

${ }^{89}$ Ajates Gonzalez, 'Going back' 283.

90 Fonte and Cucco, 'Cooperatives' 292, 293.

91 On multi-stakeholder cooperatives see Hans Münkner, 'Multi-stakeholder co-operatives and their legal framework' in Carlo Borzaga and Roger Spear (eds), Trends and challenges for co-operatives and social enterprises in developed and transition countries (Trento: Edizioni31, 2004) 49; Catherine Leviten-Reid and Brett Fairbairn, 'Multi-stakeholder Governance in Cooperative Organizations: Toward a New Framework for Research?' (2011) 2 Canadian Journal of Nonprofit and Social Economy Research - Revue canadienne de recherche sur les OBSL et l'économie sociale 25; Margaret Lund, 'Multi-stakeholder Co-operatives: Engines of Innovation for Building a Healthier Local Food System and a Healthier Economy' (2012) 45 Journal of Co-operative Studies 32; Thomas W. Gray, 'Historical tensions, institutionalization, and the need for multistakeholder cooperatives' [Commentary]. (2014) 4 Journal of Agriculture, Food Systems, and Community Development 23; Ajates Gonzalez, 'Going back'.

${ }^{2}$ Ajates Gonzalez, 'Going back' 278.
} 
in raising capital and acquiring expertise from the greater community and going beyond mutuality between supply and demand side members. ${ }^{93}$

As such multi-stakeholderism is not anything new: members of cooperative banks consist both savers and borrowers albeit changing these roles in the course of time. The change in roles is not so rare either in agrifood, as farmers are also consumers and consumers are also workers. ${ }^{94}$ The main issue is in a value chain thinking: as opposed to a narrow supply chain or demand chain thinking, comprehensive value chain thinking enables connecting the many cultural and societal aspects of both production and consumption as taste, identity, commitment, support, connection with nature, and community, that are ignored in financial exchanges. By fostering long-term relationships rather than punctual commercial transactions, multi-stakeholder cooperatives can be transformational and overcome the higher transactional costs that traditional economic theory would expect from the involvement of several parties. ${ }^{95}$ The multistakeholderism can be taken into consideration with voting rights, for instance in Manchester Veg People local food cooperative, the voting is weighted as follows: 45 per cent growers, 30 per cent buyers (including restaurants, caterers and public sector organisations as the University of Manchester and Manchester City Council), and 25 per cent workers, to prevent the replication of power imbalances found in the conventional food systems. ${ }^{96}$

What makes the difference between a traditional crowdfunding and cooperative crowdfunding is however platform ownership: is the crowdfunding part of centralized platform capitalism organized by commercial platform providers or control the members themselves the platform through a cooperative. A platform cooperative is an alternative form of platform ownership and governance through equity crowdfunding and equity shares for users in the value chain, supporters, municipalities, consumer organizations and voluntary organizations, creating a genuine multi-stakeholder cooperative. ${ }^{97}$ Among the new cooperative movement seems these user owned and governed platform cooperatives to be among the most active. ${ }^{98}$ Examples of platform cooperatives are in second hand market, home sharing and car sharing. ${ }^{99}$ Key advantages of cooperatives are in cost effectiveness (in principle, no fees to be distributed to commercial platforms), data protection (privacy can be ensured vis-à-vis both corporations and governments) and value sharing between members. ${ }^{100}$

\footnotetext{
93 Timothy Petrou, 'Chapter 12: Canada' in Dante Cracogna, Antonio Fici and Hagen Henrÿ (eds.) International Handbook of Cooperative Law (Heidelberg: Springer, 2013) 289, 299-300.

${ }^{94}$ Ajates Gonzalez, 'Going back' 280.

95 Ajates Gonzalez, 'Going back' 280.

96 Ajates Gonzalez, 'Going back' 281-282.

97 Koen Frenken, 'Political economies and environmental futures for the sharing economy' (2017) 375 Philosophical Transactions of the Royal Society A 20160367, rsta.royalsocietypublishing.org.

98 See for instance Trebor Scholz, Platform Cooperativism vs. Sharing Economy, Medium (4 December

2014) <https://medium.com/@trebors/platform-cooperativism-vs-the-sharing-economy-2ea737f1b5ad> accessed 4 March 2018; Trebor Scholz and Nathan Schneider (eds.) Ours to Hack and to Own: The Rise of Platform Cooperativism, A New Vision for the Future of Work and a Fairer Internet (OR Books 2016); see also Platform Cooperativism Consortium <https://platform.coop> accessed 4 March 2018.

${ }^{99} \mathrm{~A}$ cooperative is seen as a solution to labour exploitation in the on-demand economy, where commercial platforms exercise control over workers as platforms can decide on participation-based on reviews, with some like Uber also setting prices. By having the workers owning and controlling the platform instead, exploitative practices can be avoided by agreeing on minimum wage, work times and insurances. See Frenken, 'Political economies' 11.

100 Frenken, 'Political economies' 11.
} 


\section{Conclusions}

Startups typically begin with savings, or money from family and friends, but then tap outside private, public and hybrid investors for seed funding through a variety of channels, including lawyers, accelerators (in essence, schools for startups) and other 'angel' investors with cash to back founders with ideas. These increasingly include entrepreneurs who made money from their own startups and now invest in others. ${ }^{101}$ The startup scene is however also dominated by this clique of private equity providers and venture capitalists with privileged access to equity. ${ }^{102}$ Listed public companies are investments vehicles for the masses, they give ordinary people an imaginary stake in capitalism albeit indirectly through intermediaries.

There is however a change going on. The new corporate culture discussed in this Chapter is an attempt to answer to the problems of traditional companies, either closed or listed ones. The new startups are able to reach pools of capital that neither an old-fashioned family business nor a listed company would have got their hands on. The main advantage of the new business models presented in this Chapter is that are literally private, as ownership in these new enterprises is cut off from the rest of the economy but at the same time their activities are more connected to participation and the society.

At the same time, the unsustainability of both public listed and private equity financing forms creates pressure more societal financing that takes sustainable business models and circular economy seriously. In this Chapter a focus has been in cooperativism through crowdfunding and new cooperatives that can give ordinary people a possibility to both invest in and participate sustainable startups directly. In this Chapter the possibilities of crowdfunding and cooperatives have been scrutinized from sustainability and circularity point of views. As a result a picture of a community-based multi-stakeholder cooperative ownership is painted, reaching also to the platforms the cooperatives operate.

This picture painted is not to say that listed productive companies and other public investment forms do not have future. They have their place, especially for capital intensive industries like as such doomed oil and gas, usually however controlled for at least relatively sustainable by public entities as state owned enterprises, national holding companies and wealth funds. These companies are like limited partnerships, the public entity as a general partner and the other institutional investors as limited partners.

Secondly this is not to say that public market actors as state financing vehicles have a role only in listed companies. Public market actors take many forms for various purposes, from fully stated owned enterprises, sovereign wealth funds, public pension funds, traditional public development banks and funds to new public and hybrid venture capital investing funds, just to name few examples. In the public sector there is more and more pressure to invest to private targets instead of public listed companies that has been the traditional modus operandi of states, sovereign wealth funds and public pension funds. Public entities work however more often not lonely but in cooperation with private partners, having in the future even bigger role in capital

101 'Reinventing the deal'.

102 'Reinventing the company'. 
incentive startups, for instance in infrastructure and renewables, albeit being yet something new and challenging for the states due to cautiousness of their governments. ${ }^{103}$

Thirdly, and finally, the picture painted challenges the claim that cooperatives are as such fundamentally different from companies, and so as business models, antagonistic. As we have seen, such a dichotomy does not allow us to fully grasp the complexity of the relation between the cooperativism and corporate businesses, particularly taking into consideration cooperative business models' recent transformations. ${ }^{104}$

103 See for instance Gwladys Fouche, 'Norway fund should be able to invest in unlisted renewables - ruling party' Reuters 7 April 2018, < https://www.reuters.com/article/us-norway-swf/norways-wealth-should-be-allowedto-invest-in-unlisted-renewables-ruling-conservative-party-idUSKBN1HE0N7> accessed 3 May 2018.

104 Forney and Häberli, 'Cooperative values' 245. 